\title{
UKM Berbasis Inovasi di Jawa Timur dan Ekspansi Bisnis UKM
}

Artikel yang berjudul "Pengembangan UKM Berbasis Inovasi di Provinsi Jawa Timur: Periode 2010 - 2014" ini disusun oleh Andre Hermanto, Ahmad Zafrullah Tayibnapis, dan Idfi Seyaningrum. Artikel ini menjelaskan tentang perekonomian Indonesia, contoh inovasi-inovasi UKM, di Jawa Timur dan berbagai strategi dan saran untuk UKM.

Indonesia mengalami defisit pada perekonomiannya karena daya saing yang rendah dibandingkan dengan negara China. Negara China memiliki harga produk yang cenderung lebih murah daripada harga produk Indonesia. Hal ini mengakibatkan jumlah barang import semakin melonjak naik sedangkan jumlah ekspornya lebih kecil daripada jumlah import.

Usaha Kecil Menengah atau yang biasa disebut UKM ini memiliki pengaruh dalam memperbaiki perekonomian Indonesia meskipun UKM terlihat kecil, namun dengan jumlah yang banyak UKM dapat mempengaruhi perekonomian Indonesia. Salah satunya UKM pada provinsi Jawa Timur yang membantu perekonomian di Jawa Timur yang dibuktikan dengan besarnya angka pertumbuhan ekonomi, Produk Domestik Regional Bruto (PDRB), pendapatan per kapita yang semakin meningkat setiap tahunnya. Pada metode penelitiannya, artikel ini menggunakan SWOT Analysis untuk menyusun strategi pengembangan UKM di Jawa Timur. Adapun macam-macam SWOT Analysis yaitu Strategi Kekuatan dan Peluang (S-O), Strategi Peluang dan Kelemahan (W-O), Strategi Kekuatan dan Ancaman (S-T), dan Startegi Ancaman dan Kelemahan (W-T). Strategi-strategi yang diberikan pada artikel ini memberikan nilai tambahan yaitu dapat membantu UKM dalam bersaing.

Dalam penelitiannya, artikel ini menjelaskan bahwa penduduk Jawa Timur pada data BPS tahun 2015 berjumlah 37.476.011 jiwa dengan jumlah pengangguran di Jawa Timur sebanyak 821.546 jiwa, dan dengan jumlah kemiskinan di Jawa Timur sebanyak 5.529.300 jiwa. Karena data tersebut merupakan data yang diambil di tahun 2015 sehingga data tersebut sudah kurang relevan dengan masa sekarang. Namun, Jawa Timur masih memiliki potensi dimana persentase pertumbuhan ekonomi di Jawa Timur pada 2012 tergolong tinggi yaitu sebesar 7,27\% yang tidak terlepas dari adanya kontribusi UMKM dan koperasi terhadap PDRB (Pendapatan Domestik Regional Bruto) sebesar 54.34\% yang akhirnya mempengaruhi tingkat pertumbuhan ekonomi Jawa Timur. Melalui data yang diberikan ada artikel tersebut, penulis tidak memberikan grafik yang mendukung data-data tersebut. Beberapa sektor yang dominan dalam menyumbangkan PDRB provinsi Jawa Timur yaitu pertanian, pengolahan, perdagangan, hotel, dan restoran. Sektor-sektor tersebut tidak terlepas dari kontribusi UKM di Jawa Timur.

Artikel ini juga memberikan data UKM yang berbasis inovasi yang sesuai dengan fakta. Melalui data UKM di Jawa Timur yang tercantum, penulis artikel memanfaatkannya untuk melakukan SWOT Analysis dalam 
meningkatkan pertumbuhan UKM berbasis inovasi di Jawa Timur.

Kesimpulan yang dapat diambil dari analisis tersebut adalah pertumbuhan dan pengembangan UKM yang berbasis inovasi dalam meningkatkan pertumbuhan ekonomi dan mengurangi pengangguran. Namun, masih terdapat masalah dalam UKM yaitu kesiapan UKM dalam menghadapi persaingan global, lemahnya akses informasi dalam akses pasar dan teknologi, dan banyaknya produk yang datang dari Tiongkok. Oleh karena itu, saran yang dapat diberikan untuk kemajuan UKM yaitu sebaiknya bagi pemerintah untuk dapat mengurangi pajak, kemudahan birokrasi, penciptaan iklim yang kondusif, bantuan akan pendanaan, dan pelatihan; bagi pihak lain untuk turut berpartisipasi dengan pemberian kredit dan pendannaan lainnya; bagi pelaku UKM untuk melakukan pendekatan dengan supplier untuk menjamin tersedianya bahan baku dan supaya lebih cermat dan cerdik terkait dengan persaingan yang ketat.

Setiap bisnis harus melakukan ekspansi terhadap bisnisnya. Mereka harus melakukan pengembangan terhadap bisnisnya agar tetap berjalan dan terus berkembang. Pemilik bisnis harus memiliki gambaran yang jelas mengenai bisnisnya di masa sekarang ini dan mempunyai ideide baru yang sesuai dengan perkembangan zaman.

Mereka harus melakukan ekspansi bisnis agar perusahaan tetap aman, menguji dan membuktikan ide manajemen dan produk, dapat memberikan kesempatan pengembangan karir staf perusahaan, dapat meningkatkan daya saing perusahaan, dapat menjamin kualitas produk, dan lain-lain. Dalam melakukan ekspansi bisnis, hal utama yang sangat dibutuhkan yaitu pendaaan untuk ekspansi bisnisnya. Dalam menentukan kebutuhan dana untuk ekspansi bisnis ada tiga tahap yang harus dilakukan diantaranya adalah sebagai beikut.

a. Mengestimasi volume penjualan

Dalam mengestimasi volume penjualan, pebisnis harus mempertimbangkan jumlah perusahaan lain yang bergerak dibidang yang sama, menentukan jumlah dan kemampuang pesaing, menyesuaikan kemampuan bersaing dengan daya beli pelanggan, dan mempertimbangkan arah perkembangan bisnis.

b. Mengestimasi biaya ekspansi awal

Biaya ekspansi awal yang diestimasi terdiri dari perlengkapan dan peralatan dan biaya instalasi, dekorasi dan mengubah bentuk produk, persediaan, dan periklanan dan promosi.

c. Beban-beban operasional

Beban-beban operasional yang diestimasi diklasifikasikan berdasarkan gaji, persediaan, sewa, iklan, beban pengangkutan, perlengkapan kantor, pajak, utilitas, pemeliharaan.

Dalam melakukan ekspansi bisnis, seringkali para pemilik UKM khawatir terhadap keuangan yang dihasilkan. Hal tersebut dapat diatasi dengan melakukan pembukuan yang benar pada bisninya. Akuntansi dapat membantu para pemilik UKM dalam mengambil keputusannya karena dengan melakukan pembukuan mereka akan 
mengetahui laba/rugi yang diperoleh, tambahan modal yang dicapai, keseimbangan hak dan kewajiban. Sehingga pemilik UKM akan mengetahui kondosi konkret akan keuangannya dan mereka dapat mengambil keputusan untuk melakukan ekspansi bisninya.

\section{Daftar Pustaka}

Hermanto, Andre, Tayibnapis, Ahmad Zafrullah, dan Setyaningrum, Idfi, Strategi Pengembangan UKM Berbasis Inovasi di Provinsi Jawa Timur: Periode 2012-2014, Ekonomi dan Bisnis: Berkala Publikasi Gagasan Konseptual, Hasil Penelitian, Kajian, dan Terapan Teori, Vol. 20 No.2, ISSN 1410-9204, 2016.

Andres. (2011). Manajemen Keuangan UKM. Yogyakarta: Graha IImu.

Suryo, Anak. Akuntansi untuk UKM: Metode Akuntansi Praktis dan Sederhana Untuk Usaha Kecil dan Menengah. Yogyakarta: PT. Agromedia Pustaka.

Kelompok 9:

Nico Abertnego/ KP D/ 130318146

Richard Agung/ KP D/ 130318148

Cindy Alexandra/ KP D/130318150

Johanna Berliana/ KP D/ 130318161 